\section{A Call to Use Cultural Competence When Teaching Evolution to Religious College Students: Introducing Religious Cultural Competence in Evolution Education (ReCCEE)}

\author{
M. Elizabeth Barnes and Sara E. Brownell* \\ Biology Education Research Lab, School of Life Sciences, Arizona State University, \\ Tempe, AZ 85287
}

\begin{abstract}
Low acceptance of evolution among undergraduate students is common and is best predicted by religious beliefs. Decreasing students' perceived conflict between religion and evolution could increase their acceptance of evolution. However, college biology instructors may struggle with trying to decrease students' perceived conflict between religion and evolution because of differences in the religious cultures and beliefs of instructors and students. Although a large percentage of undergraduate students in evolution courses are religious, most instructors teaching evolution are not. To consider differences between the secular culture of many college instructors and the religious culture of many students, we propose using a lens of cultural competence to create effective evolution education. Cultural competence is the ability of individuals from one culture (in this case, primarily secular instructors who are teaching evolution) to bridge cultural differences and effectively communicate with individuals from a different culture (in this case, primarily religious undergraduate biology students). We call this new framework Religious Cultural Competence in Evolution Education (ReCCEE). In this essay, we describe a suite of culturally competent practices that can help instructors reduce students' perceived conflict between evolution and religion, increase students' acceptance of evolution, and help create more inclusive undergraduate biology classrooms.
\end{abstract}

If $80-90 \%$ of Americans profess that (they believe in God) and they think that evolution is against religion, then we (scientists) are not going to get very far... so the main reason we have to keep stressing that science is a different matter and is not opposed to religion...is that it happens to be right logically, but we should also be aware that it is very practical.

-Stephen J. Gould, annual meeting of the American Institute of Biological Sciences in the Museum of Natural History, Smithsonian Institution, Washington, DC, 2000

At the annual meeting of the American Institute of Biological Sciences in March 2000, Stephen J. Gould, a champion of evolutionary theory, highlighted his distress to biologists about the current state of evolution education. He noted that a large percentage of the American public rejected evolution because of a perceived conflict between religion and science. Despite Gould's own agnostic beliefs, he insisted that the scientific community take steps to relieve the tension between scientific and religious communities to advance evolution education. He predicted that we would not see a change in the rates of rejection of evolution if the scientific community continued to assert that evolutionary theory must be in opposition to religion.
Kathryn E. Perez, Monitoring Editor Submitted April 6, 2017; Revised August 4, 2017: Accepted August 7, 2017

CBE Life Sci Educ December 1, 2017 16:es4 DOI:10.1187/cbe.17-04-0062

*Address correspondence to: Sara E. Brownell (Sara.brownell(aasu.edu).

(C) 2017 M. E. Barnes and S. E. Brownell. CBE-Life Sciences Education () 2017 The American Society for Cell Biology. This article is distributed by The American Society for Cell Biology under license from the author(s). It is available to the public under an Attribution-Noncommercial-Share Alike 3.0 Unported Creative Commons License (http://creativecommons.org/licenses/ by-nc-sa/3.0).

"ASCB®" and "The American Society for Cell Biology ${ }^{\circledR}$ " are registered trademarks of The American Society for Cell Biology. 
When Gould raised attention about this issue, the national Gallup poll reported that $44 \%$ of Americans believed that "Humans were created in their current form by God in the last 10,000 years," and 17 years later, the rates of rejection of evolution in the United States have remained around 40\% (Gallup, 2017). Further, the research literature indicates that the perceived conflict between evolution and religion may be exacerbated by differences in the religious cultures and religious beliefs of scientists and the public. If we are to change the public's attitude toward evolution, we must find a way to bridge this cultural divide.

In this essay, we will introduce the use of cultural competence as a way to bridge the religious cultural gap between scientists and the public. Cultural competence could be particularly effective for helping secular college instructors teach evolution to religious undergraduate biology students. We will use cultural competence as a lens to build a new framework of instructional practices that evolution instructors can use to more effectively teach evolution to religious students: Religious Cultural Competence in Evolution Education (ReCCEE, pronounced "ree-see"). This framework encompasses a set of evidence-based instructional practices that can help minimize the negative impact of differences between the predominantly secular cultures of evolution instructors and the religious cultures of many of their students. The goal of this essay is to convince readers that the use of cultural competence in undergraduate evolution education can decrease students' perceived conflict between evolution and religion, increase students' acceptance of evolution, and enable religious students to feel more included in undergraduate biology classrooms.

\section{RELIGIOSITY IS THE MAIN FACTOR THAT NEGATIVELY PREDICTS ACCEPTANCE OF EVOLUTION}

Evolution is simultaneously one of the most influential theories in science and one of the most controversial. More than 30 years of public polls show that only approximately $60 \%$ of Americans accept that humans have developed from previous species (Gallup, 2017). Although rates of acceptance of evolution among undergraduates vary by geographic region and institution, and some of this reported variation may be due to different methods of measuring acceptance of evolution, ${ }^{1}$ research has shown that acceptance of evolution is weak among college students. For instance, one study found that approximately half of students at a large research university did not accept that evolution could occur without the intervention of an intelligent designer (Brem et al., 2003). Another study demonstrated that students in a nonmajors biology course had low to moderate acceptance of evolution, according to their scores on the

\footnotetext{
${ }^{1}$ Acceptance of evolution is a construct that has been frequently measured using different instruments. The different ways that researchers measure acceptance of evolution can lead to different results across studies, because the items and the way items are worded are different. Examples of instruments include the MATE (Rutledge and Sadler, 2007), the Inventory of Student Acceptance of Evolution (I-SEA; Nadelson and Southerland, 2012), and the Generalized Acceptance of Evolution Evaluation (GAENE) scale (Smith et al., 2016). Additionally, many studies use instructor-generated single-item questions about acceptance of evolution. The lack of consistency in the definition and measures of acceptance of evolution has been critiqued in the literature (Smith, 2009a). These different measures make it difficult to draw conclusions about student acceptance of evolution across studies.
}

Measure of Acceptance of the Theory of Evolution (MATE; Rutledge and Sadler, 2007; Walter et al., 2013). Even among junior- and senior-level biology majors, one study identified that $28 \%$ did not accept that life on Earth shares a common ancestor (Ingram and Nelson, 2006). For a review that summarizes low acceptance rates of evolution among college students, see Rice et al. (2010).

Why do we see low levels of acceptance of evolution? Thus far, research illustrates that acceptance of evolution is a multifaceted and complex phenomenon with many causal factors (Rutledge and Warden, 2000; Wiles and Alters, 2011; Winslow et al., 2011), but a person's religious beliefs and how important those beliefs are to him or her-defined as religiosity-is the greatest predictor of whether someone will accept evolution (Hill, 2014; Glaze et al., 2014; Rissler et al., 2014). For instance, Glaze et al. (2014) used multiple-regression analysis to determine that religiosity was the most predictive factor for acceptance of evolution; student religiosity explained twice as much variance in acceptance of evolution as student understanding of evolution did. Further, Hill (2014) found that individuals who were special creationists in their teens were approximately three times more likely to accept evolution by their twenties if they were not strongly committed to their religious beliefs as teenagers. Additionally, the individuals in this study were seven times more likely to change to accepting evolution if one of their close friends or family members accepted evolution. Interestingly, increased education levels (i.e., obtaining a bachelor or graduate degree) were not predictive of whether these individuals would eventually accept evolution.

A person's acceptance of evolution can be impervious to instruction about evolution. Some studies have shown that students do not show a statistically significant increase in their acceptance of evolution scores after being taught about evolution (Walter et al., 2013; Short and Hawley, 2015). Other studies have shown that student understanding of evolution is not associated, or only weakly associated, with levels of acceptance of evolution. For instance, Nadelson and Sinatra (2010) found no correlation between preservice teachers' scores on the Conceptual Inventory of Natural Selection (CINS; Anderson et al., 2002) and their scores on the MATE. Bishop and Anderson (1990) found that students' ability to explain natural selection and changes in populations was unrelated to whether the students thought evolution was true. Another study showed no relationship between students' scores on the Understanding Biological Change (UBC) survey (Settlage and Jensen, 1996) and their beliefs about the credibility of evolution (Sinatra et al., 2003). While some studies have shown weak relationships between acceptance of evolution and understanding of evolution (Deniz et al., 2008; Nadelson and Sinatra, 2009; Cavallo et al., 2011; Athanasiou and Papadopoulou, 2012; Großschedl et al., 2014), the research is clear that students' religious beliefs and the beliefs of their family and friends more strongly predict whether they will accept evolution. Why does religiosity so strongly determine one's acceptance of evolution?

One possibility is that many religious individuals perceive a conflict between their religious beliefs and evolution. This message of conflict is often propagated in classrooms, religious institutions, popular culture, and the media by scientists, teachers, religious leaders, and politicians. Some evolutionary 
biologists have written books that claim evolution and religion must be in conflict (Dawkins, 2009; Coyne, 2015) and some religious leaders position religion against evolution, claiming that one must relinquish one's faith to accept evolution (Ham, 2010). There has even been a multimillion dollar creationist museum established with the purpose of using religious claims to discredit evolutionary theory (Kopplin et al., 2016). Further, politicians at the state and national levels have advocated for the teaching of creationism as an alternative to evolution in public schools, further stoking the belief that religion and science have to be in opposition (Satlin, 2012; Kaplan, 2016). Owing to the visibility of these polarizing positions, it is not surprising that individuals may feel as though they must reject their religious beliefs if they are to accept evolution.

Although it may sometimes seem as if only two extreme positions exist-being atheist and accepting evolution or being religious and not accepting evolution-there is room for conciliation between evolution and religion. Calls for acknowledging the potential for a nonconflicting relationship between evolution and religion have been prevalent in the evolution education literature (Cobern, 1994; Jackson et al., 1995; Smith, 2009a,b; Southerland and Scharmann, 2013; Scott, 2014). The Catholic church has made official statements that Catholic religious doctrines are compatible with evolution (Tharoor, 2014), and $\sim 14,000$ religious leaders have signed a letter supporting potential compatibility between evolution and religion (Clergy Letter Project, 2016). The National Academy of Sciences (NAS) has produced reports that highlight the potential compatibility of evolution and religion (NAS, 1998, 2008), and the Smithsonian Institution has created materials outlining how high school teachers can teach evolution to high school students while remaining sensitive to these students' religious beliefs (Smithsonian Institution, 2015). In fact, studies show that acknowledging potential compatibility between evolution and religion can increase student acceptance of evolution (Manwaring et al., 2015) and decrease perceived conflict between evolution and religion (Barnes et al., 2017a, 2018). However, might there be characteristics of evolution instructors that make it difficult for them to acknowledge the potential compatibility between religion and evolution?

\section{THE DIFFERENCE BETWEEN THE RELIGIOUS BELIEFS AND CULTURES OF STUDENTS AND INSTRUCTORS IN COLLEGE BIOLOGY CLASSES}

The majority of the public holds religious beliefs (Pew Research Center, 2010), and we found that the majority of surveyed college students in biology classes at a large research university reported being religious (Table 1). In contrast, it has been shown that only $25 \%$ of biologists are religious (Ecklund and
Scheitle, 2007), and evolutionary biologists in particular are markedly irreligious; only $10 \%$ of evolutionary biologists say that they believe in a God/god(s) (Graffin and Provine, 2007). Although the term "religious beliefs" can be hard to define (Hill and Pargament, 2003), we define "religious beliefs" in this essay as the specific beliefs one holds about the existence and influence of a deity (Merriam-Webster, 2017b). We define being "religious" as having faithful devotion to an acknowledged ultimate reality or deity (Merriam-Webster, 2017c). Yet a person's religious identity includes both religious beliefs and religious culture.

In line with broader definitions of culture (Merriam-Webster, 2017a), we define "religious culture" as the sociocultural norms related to religion. Religious cultural norms can include shared values, attitudes, traditions, holidays, and celebrations. An individual who is religious would likely participate in some, if not most, of his or her religion's customs. However, an individual can be culturally religious, but not ascribe to the specific religious beliefs of that religion. For example, an individual may participate in religious events or customs (e.g., attending church services on Christmas Eve, observing Passover, giving up chocolate for Lent), but not believe in the existence of a deity. Although many evolution instructors do not hold religious beliefs, they may still participate in a religious culture, which could influence their awareness of and sensitivity to religious objections to evolution.

Alternatively, an individual can be part of a culture that is secular. A secular culture can have no social norms or expectations regarding religion or a secular culture can have sociocultural norms that are overtly opposed to religion and religious groups. While we know of no specific studies exploring the differences in religious cultures between biology instructors and biology students, the pursuit of science is often assumed to be a secular endeavor (Jackson et al., 1995), and many evolutionary biologists who model the culture of science to the public often espouse views that are in opposition to religion and religious individuals (Dawkins, 2009; Coyne, 2015). Therefore, instructors of evolution may ascribe to a secular culture that includes norms that are opposed to religion or promote negative stereotypes about religious individuals, which could negatively influence their ability to effectively communicate evolution to religious individuals.

Even though there is a notable difference between the percentages of religious students in biology classes and the percentages of biologists with a religious identity, the question remains whether this difference in religious beliefs and cultures matters for instructional practices when teaching evolution. There is an emerging research literature that suggests that it does.

TABLE 1. Rates of religiosity among students in biology classes at a large southwestern R1 university in Arizona ${ }^{\mathrm{a}}$

\begin{tabular}{llccc}
\hline Semester & \multicolumn{1}{c}{ Population } & Sample size & $\begin{array}{c}\text { \% Self-identified } \\
\text { with a religion }\end{array}$ & $\begin{array}{c}\text { \% Who agree religion is an } \\
\text { important part of their identity }\end{array}$ \\
\hline 2014 Fall & Introductory biology students & 1440 & 64 & 55 \\
2016 Fall & Introductory biology and upper-level biology students & 462 & 79 & 45 \\
2017 Spring & Upper-level evolution students & 389 & 77 & 40 \\
\hline
\end{tabular}

${ }^{\mathrm{a}}$ Arizona ranks 24 th in religiosity among all U.S. states, with $51 \%$ of residents reporting that religion is important to their lives. Students completed an online survey that asked them to self-identify their religious affiliations and to what extent their religious affiliations were important to their identities. Students could decline to state. 
Prior research from our group indicates that college evolution instructors' previous and current religious beliefs and cultures may impact their teaching of evolution and the degree to which they are willing to help students with religious beliefs become more comfortable with evolution. In an interview study with college biology instructors who teach evolution at public institutions, we found that many instructors were reluctant to address potential compatibility between evolution and religion, because they did not feel that discussions about religion had a place in the biology classroom (Barnes and Brownell, 2016). Yet many of these instructors seemed to be unaware of the struggles of religious students in their biology classes. This may be because many of these instructors did not know how many of their students were religious or to what degree these students perceived a conflict between their religious beliefs and evolution. Additionally, most of the instructors were not religious themselves and had never experienced their own worldview conflict between evolution and their religious beliefs, which mirrors what we know about biologists broadly (Ecklund and Scheitle, 2007; Pew Research Center, 2009). Notably, many instructors had their own beliefs that evolution and religion must be in conflict; some of these instructors taught evolution as fundamentally atheistic and even overtly made disparaging remarks about religion during class.

Not acknowledging religious beliefs can be alienating for religious students (Hermann, 2012; Barnes et al., 2017b). In an interview study with religious students in undergraduate biology classes, we found that students assumed that instructors were not accepting of students' religious beliefs when instructors avoided discussion about religious beliefs when teaching evolution. Many religious students also assumed that most biology instructors were not religious and did not know of scientist role models who reflected their own religious identity and accept evolution (Barnes et al., 2017b). Similarly, an interview study done with high school students learning evolution demonstrated that, when instructors did not acknowledge students' religious beliefs, the religious students in the class felt left out (Hermann, 2012). This small, yet growing, literature base illustrates that we may be creating less inclusive classroom environments by not addressing religious beliefs when teaching evolution.

Our work and the work of others are beginning to illustrate that students' perceived conflict between evolution and religion, their rejection of evolution, and their feelings of not belonging in the biology classroom may be, in part, the result of the difference in culture between mostly secular instructors and mostly religious students (Jackson et al., 1995; Smith, 2009b; Hermann, 2012; Southerland and Scharmann, 2013; Barnes and Brownell, 2016). A potential solution is to try to help secular evolution instructors better understand and relate to the cultures of religious students.

\section{THE USE OF RELIGIOUS CULTURAL COMPETENCE IN EVOLUTION EDUCATION (ReCCEE) TO BRIDGE THE RELIGIOUS CULTURAL GAP}

Cultural competence refers to the ability of people of one culture to understand and relate to the people of another culture (Tanner and Allen, 2007). Cultural differences, including differences in gender, ethnicity, country of origin, LGBTQIA identity, or religion can make it more difficult for two people to understand each other, communicate with each other, and work effectively with each other. Cultural competence has been called for as a lens to help people bridge cultural gaps to help communicate more effectively. Cultural competence has been previously discussed in the context of doctors treating patients (Betancourt et al., 2003; Tervalon and Murray-García, 2010), managers supervising employees (Johnson et al., 2006), and instructors teaching students (Tanner and Allen, 2007). Betancourt et al. (2003, p. 294) defined cultural competence as acknowledging "the importance of culture, assessment of cross-cultural relations, vigilance toward the dynamics that result from cultural differences, expansion of cultural knowledge, and adaptation of services to meet culturally unique needs." Although cultural competence has been recommended for college biology instructors (Tanner and Allen, 2007), to our knowledge it has never been specifically advocated for as a lens to bridge the cultural gap between nonreligious instructors teaching evolution and religious students, even though student religious beliefs are a major factor in why students do not accept evolution.

Previous studies have shown that cultural competence training can improve provider and patient outcomes in medicine and counseling. One study showed that physicians who underwent training in cultural competence became more aware of racial disparities in the healthcare of Black patients compared with physicians who did not complete training (Sequist et al., 2010). Another study found that physician training in cultural competence improved racial minority patient perceptions of physicians (Harmsen et al., 2005). Finally, a study found that when counselors were trained in cultural competence, their Black female patients returned for appointments more often, showed greater satisfaction with counseling services, perceived their counselors as more credible, and scored higher on patient-counselor relationship measures than did Black female patients with counselors who were not trained in cultural competence (Wade and Bernstein, 1991). Given that student perceptions of scientists, including their trust in scientists, has been shown to influence students' acceptance of evolution (Nadelson and Hardy, 2015), the positive results from physician/counselor training in cultural competence are promising for evolution education. Cultural competence training for evolution instructors could result in improved instructor relationships with religious students; improved student perceptions of evolution instructors, in the form of higher credibility and trustworthiness; and higher student satisfaction with evolution instruction broadly.

The lens of cultural competence can be used to help organize evolution education teaching practices that may bridge the gap between the predominantly secular cultures of college biology instructors and the religious cultures of many students. Although these practices have already been reported in the literature as impactful for increasing student acceptance of evolution or decreasing perceived conflict between evolution and religion, a framework that organizes these evidence-based practices does not currently exist. To help evolution instructors identify the commonalities among these practices and to encourage the use of these practices as a whole, we define ReCCEE as a framework for culturally competent evolution education. In this article, we describe ReCCEE practices and the empirical support for each of these practices (see Table 2 for a summary). While few studies have examined any single 
TABLE 2. ReCCEE practices and citations supporting them

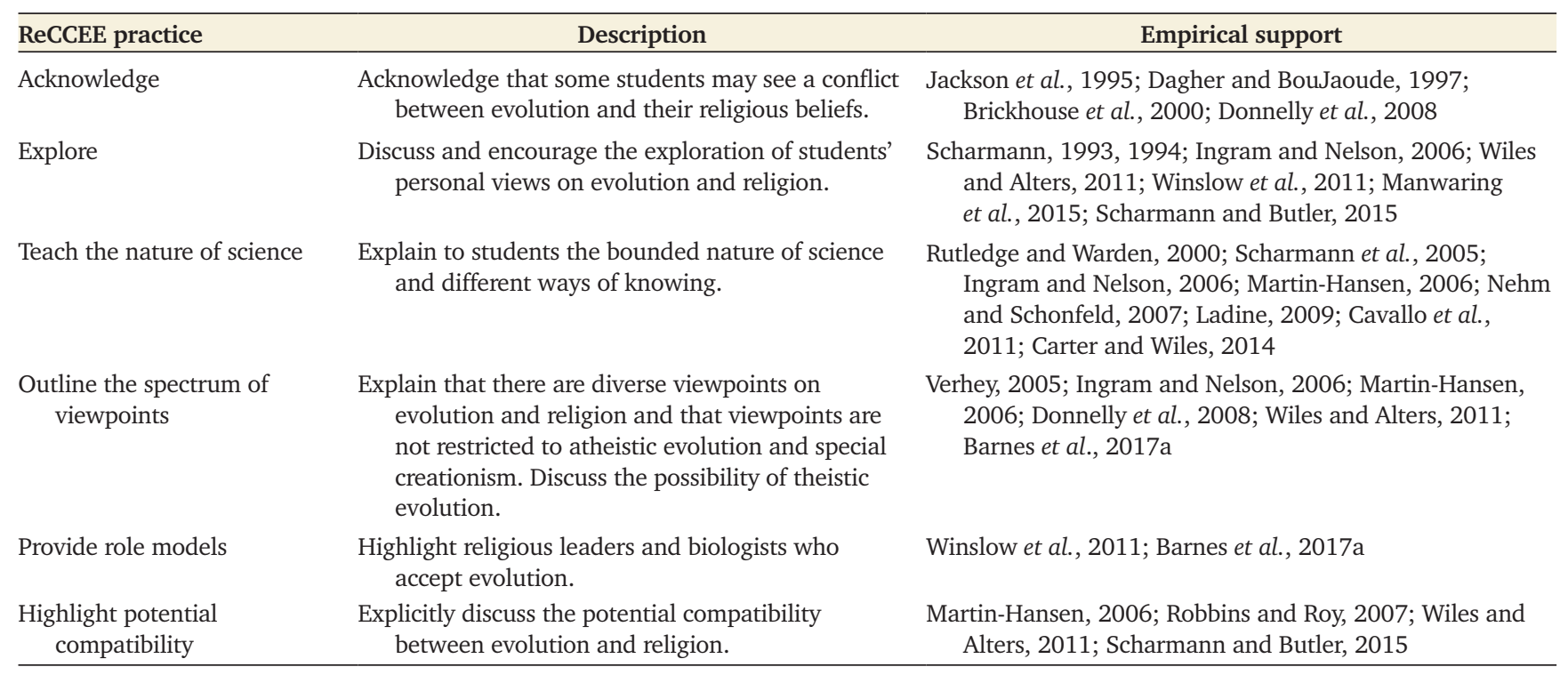

practice in isolation, there is a growing literature base for the positive impact of combinations of these practices. We outline six evidence-based culturally competent practices that instructors can use when teaching evolution to undergraduate students to help reduce students' perceived conflict between evolution and religion, increase their acceptance of evolution, and create a more inclusive classroom environment for religious students.

\section{Acknowledge That Some Students May Perceive a Conflict between Their Religious Beliefs and Evolution}

A culturally competent instructional practice that evolution instructors can use is to simply acknowledge that students may experience a conflict with their religious beliefs when learning evolution. Interview studies with students from a wide range of religious cultural backgrounds, including Muslim and Christian students in high school and college, have revealed that students appreciate when an instructor acknowledges that students can experience a conflict between their religious beliefs and evolution; instructors acknowledging a possible conflict can help students develop more positive attitudes toward evolution (Dagher and BouJaoude, 1997; Brickhouse et al., 2000). This strategy can help religious students feel respected by their instructors.

\section{Explore Students' Personal Views on Evolution and Religion}

Another culturally competent instructional practice for evolution instructors is to provide opportunities for students to discuss/reflect on their own and other students' views on evolution and religion. More so than simply acknowledging that students have different beliefs, this practice allows students to engage and reflect critically on their personal views on evolution. Winslow et al. (2011) interviewed biology majors who took a class in which they had to extensively reflect on their own and others' views on evolution and found that almost every one of these students changed from a special creationist view to accepting evolution by the time they graduated. Scharmann and Butler (2015) tested the impact of students writing in journals about their views on evolution coupled with an in-class discussion about what students had written in their journals. They found a statistically significant increase in students' positive attitudes toward evolution over their journaling experience. Finally, Scharmann (1990) has argued for student-centered discussions in class as a means for students to carefully examine their own beliefs and potentially construct their own means of reconciling their personal beliefs with evolution.

\section{Describe to Students the Bounded Nature of Science and Different Ways of Knowing}

A way to bridge the cultural gap between religious individuals and nonreligious individuals in a biology class is to discuss the nature of knowledge, different ways of knowing, and the bounded nature of science. There have been several studies that have explored the impact of these practices on students. Martin-Hansen (2006) found that extensive instruction on the relationship between science and religion, the nature of science, and the appropriate methods that science uses to test hypotheses led to increased positive attitudes of students toward evolution. Further, Ladine (2009) found that Christian students preferred that evolution instructors use the nature of science to describe the characteristics of special creationism and intelligent design that classify them as nonscientific. Ingram and Nelson (2006) demonstrated statistically significant gains in students' pre- to postcourse acceptance of evolution after incorporating the nature and limits of scientific knowledge into their evolution instruction. Similarly, Nehm and Schonfeld (2007) found that discussions about the nature of science were able to reduce high school teachers' perceived conflict between evolution and religion. Finally, several studies show a generally positive relationship between a student's understanding of the nature of science and his or her acceptance of evolution (Rutledge and Warden, 2000; Scharmann et al., 2005; Cavallo et al., 2011; Carter and Wiles, 2014). These studies suggest that instructors can be more culturally competent in their evolution instruction if they teach the nature of science. 


\section{Outline a Spectrum of Viewpoints on Religion and Evolution}

College evolution instructors can reduce students' perceived conflict between evolution and religion by helping students become aware that there is a spectrum of viewpoints on the relationship between evolution and religion. Owing to the polarizing viewpoints often presented, many students are unaware that there are more viewpoints than atheistic evolution and special creationism. ${ }^{2}$ Past research illustrates that instructors can help students decrease their perceived conflict with evolution by acknowledging and describing other viewpoints (Barnes et al., 2017a). Describing the range of viewpoints on the relationship between religion and evolution may help students identify positions that allow their religious beliefs to coexist with evolution (e.g., theistic evolution; Miller, 1999). It has been shown that instructors teaching students about different ways that people have chosen to interpret the Bible increased students' acceptance of evolution (Martin-Hansen, 2006). Specifically, these instructors told students that if they did not interpret certain parts of the Bible literally, as many religious leaders and scientists have chosen not to, then they did not have to reject evolution. This research highlights how discussing multiple viewpoints can help students reconcile their religious beliefs with evolution.

\section{Provide Students with Religious Role Models Who Accept Evolution}

Evolution instructors can also reduce perceived conflict between evolution and religion by helping students become aware of role models who are religious and accept evolution. Some students come into our classrooms with the misconception that one must either be an atheist who accepts evolution or a person of faith who rejects evolution (Barnes et al., 2017a). Although secular instructors cannot present themselves as religious role models, they can offer examples of other scientists who are religious and accept evolution or religious leaders who accept evolution. For instance, Winslow et al. (2011) interviewed students who changed from believing special creationism to accepting evolution by the end of their biology degree and asked them what the most important factor was in their decision to change. These students said one of the most important factors was positive role models in the form of their religious professors who accepted evolution. In a study done with high school students, researchers showed an increase in students' acceptance of evolution as measured by the MATE after they attended a seminar series in which individuals from different

\footnotetext{
${ }^{2}$ Atheistic evolution refers to the belief that life on Earth evolved from a common ancestor and there was no involvement of a God/god(s) in the process of evolution. Special creationism refers to the belief that species were created in their current form by a God/god(s). There are many more viewpoints on the relationship between evolution and religion that fall in between special creationism and evolution, but agnostic evolution and theistic evolution are the only ones from a philosophy of science perspective that can be reconciled with the scientific evidence for evolution. There are some biologists, however, who do not believe the istic evolution is compatible with evolution. Theistic evolution refers to the belief that life on earth evolved from a common ancestor and that a God/god(s) planned, influenced, or guided the evolutionary process. For a more exhaustive review of positions on religion and evolution see Yasri and Mancy (2016). Further, for a relevant review of viewpoints on the relationship between science and religion broadly, see Barbour (1990).
}

religious denominations who were also accepting of evolution were highlighted (Wiles and Alters, 2011). Additionally, in a study from our research group, we reduced the number of introductory biology students who saw a conflict between evolution and religion by half when we had a Catholic biologist discuss his acceptance of evolution and his Catholic faith. Notably, one-third of our students specifically mentioned that they appreciated the perspective of the religious biologist visitor during the evolution instruction (Barnes et al., 2017a).

\section{Highlight the Potential Compatibility between Evolution and Religion}

Embedded in all the previously presented practices is the idea that instructors can reduce perceived conflict between evolution and religion by explicitly showing examples of how evolution and religion can be compatible. One way to decrease this conflict between evolution and religion is to be explicit about the potential compatibility between evolution and religion and to address the false dichotomy between evolution and religion (Martin-Hansen, 2006; Robbins and Roy, 2007; Wiles and Alters, 2011; Scharmann and Butler, 2015). In fact, beyond empirical studies, highlighting potential compatibility is cited across the literature in numerous essays and critical reviews as a recommended practice in evolution education (Cobern, 1994, 2004; Smith et al., 1995; Astley and Francis, 2010; Southerland and Scharmann, 2013; Scott, 2014; Glaze and Goldston, 2015).

\section{WHY AN INCLUSIVE TEACHING ENVIRONMENT COULD MATTER IN EVOLUTION EDUCATION}

While the ReCCEE practices described earlier are specific to the perceived conflict between evolution and religion, the foundation of a culturally competent teaching approach is to create an inclusive teaching environment for all students in any setting. Instructors who adopt an inclusive teaching philosophy try to effectively teach all of their students regardless of the differences between their students and themselves. These instructors make every effort to create a safe and welcoming teaching environment for all students-regardless of gender, race/ethnicity, disAbility status, LGBTQIA status, or religion. Students with certain social identities that could be perceived as stigmatized in the biology community may not feel as though their identities are welcome in the biology community (Cooper and Brownell, 2016; Barnes et al., 2017b). To help students with stigmatized identities feel more welcome in the classroom, instructors can become aware of these social identities and identify ways to make these students feel more included in the classroom and the larger discipline of biology (Schinske et al., 2016). Perhaps the most important shift in mind-set for instructors teaching evolution to religious students is to conceptualize religious beliefs as a social identity of students that is unlikely to change over the course of a semester in response to evolution instruction. Because religious students may come into the classroom with the preconception that evolution and religion must be in conflict, they will likely feel more included and respected in the evolution learning environment if this perceived conflict is addressed.

Another factor that makes using cultural competence important when teaching evolution is that religious beliefs are correlated with race/ethnicity. African-American students 
are on average more religious than their peers and also tend to have higher rejection rates of evolution (Taylor et al., 2003; Mead et al., 2015). In fact, preliminary research is suggesting that the higher rates of religiosity among African Americans and, potentially, their higher rates of rejection of evolution could contribute to the underrepresentation of African Americans in biology, as indicated by the fact that almost no $\mathrm{PhDs}$ are awarded to African Americans in evolutionary biology (National Science Foundation, National Center for Science and Engineering Statistics, 2011; Mead et al., 2015). We may be disproportionately disadvantaging African-American students if we continue to teach evolution in ways that lack religious cultural competence.

Thus, culturally competent evolution instruction has implications beyond decreasing students' perceived conflict between evolution and religion or increasing their acceptance of evolution. Culturally competent evolution instruction may be able to help the large percentage of religious students in public institutions feel more comfortable and included in their biology classes, which could contribute to their retention in biology and pursuit of scientific careers. Ultimately, this can be a way to diversify who persists in science. Even if instructors do not perceive that it is their responsibility to teach acceptance of evolution to students, culturally competent evolution education could help instructors reach their goal of inclusive teaching.
While culturally competent evolution education would be primarily directed toward religious students, it could also have positive impacts on nonreligious students. We have found that culturally competent evolution education can reduce nonreligious students' negative stereotypes about religious people in biology (e.g., religious individuals cannot do credible science, an individual cannot be both a biologist and religious; Barnes et al., 2017a). Thus, culturally competent evolution education could encourage nonreligious individuals who may become evolution instructors to teach in more culturally competent ways, creating a positive-feedback cycle of cultural competence.

\section{ADDITIONAL RESOURCES TO HELP PROMOTE CULTURALLY COMPETENT EVOLUTION INSTRUCTION}

To help instructors become more culturally competent in their evolution instruction, we have compiled a set of available resources. Table 3 provides examples of simple ReCCEE exercises that instructors can use in their classes that require only a minimal time commitment. An additional relevant resource is the Smithsonian Institution/NAS Cultural and Religious Sensitivity (CRS) Teaching Strategies Resource booklet (Smithsonian Institution, 2015): https://humanorigins.si.edu/education/teaching -evolution-through-human-examples. This booklet provides useful examples of in-class activities for high school instructors to use while teaching evolution to create a comfortable and

TABLE 3. Examples of ReCCEE activities that could be implemented when teaching evolution

\begin{tabular}{|c|c|c|}
\hline Activity & Description & ReCCEE practice \\
\hline Surveys & $\begin{array}{l}\text { Survey your students on their beliefs about religion and evolution so you know your } \\
\text { audience and can acknowledge them. Are they religious? Which religious } \\
\text { denominations do they identify with? Do they see a conflict between their } \\
\text { religious beliefs and evolution? Do they accept evolution? Then acknowledge the } \\
\text { different views that students have in class while keeping specific student beliefs } \\
\text { confidential. }\end{array}$ & Acknowledge, explore \\
\hline Journals & $\begin{array}{l}\text { Assign students a journaling activity to encourage them to reflect on their stances } \\
\text { about religion and evolution. Possible prompts include, "In your view, do you see } \\
\text { a conflict between your personal beliefs and evolution?," "Have your views on the } \\
\text { relationship between religion and evolution changed? Why or why not?" }\end{array}$ & Explore \\
\hline Reading & $\begin{array}{l}\text { Assign students to read biographies of scientists who are religious and accept } \\
\text { evolution. Try to have students read biographies of scientists from different } \\
\text { religious denominations so that each student (or as many as possible) can see his } \\
\text { or her identity reflected in at least one scientist. To make sure readings are } \\
\text { representative of all students in the class, including those without religious } \\
\text { beliefs, also include secular scientists who accept evolution. }\end{array}$ & $\begin{array}{l}\text { Provide role models who } \\
\text { accept evolution, highlight } \\
\text { potential compatibility }\end{array}$ \\
\hline Instructor presentation & $\begin{array}{l}\text { Show the official stances of different religious denominations on evolution. For } \\
\text { instance, the Catholic church officially supports evolution, while the Mormon } \\
\text { church is silent with respect to evolution. It is best to know which religious } \\
\text { denominations your students identify with to be relevant to most of your } \\
\text { students. }\end{array}$ & $\begin{array}{l}\text { Outline spectrum of views, } \\
\text { highlight potential } \\
\text { compatibility }\end{array}$ \\
\hline Group work & $\begin{array}{l}\text { Make a list of questions such as "Does God exist?," "How old is life on Earth?," "Did } \\
\text { God create humankind?," and "Do humans share a common ancestor with } \\
\text { chimpanzees?," and have students categorize and discuss which questions are } \\
\text { subject to scientific analysis, which are not, and why. }\end{array}$ & Teach the nature of science \\
\hline Instructor presentation & $\begin{array}{l}\text { Show different positions on the relationship between religion and evolution, } \\
\text { including special creationism, theistic evolution, agnostic evolution, and atheistic } \\
\text { evolution. Distinguish which of these positions is philosophically compatible with } \\
\text { the evidence from science and which are not. }\end{array}$ & $\begin{array}{l}\text { Outline the spectrum of views, } \\
\text { teach the nature of science, } \\
\text { highlight potential } \\
\text { compatibility }\end{array}$ \\
\hline Guest visitors & $\begin{array}{l}\text { Have religious scientists visit the class and talk with students about how they } \\
\text { reconcile religious beliefs and evolution. }\end{array}$ & $\begin{array}{l}\text { Provide role models, highlight } \\
\text { potential compatibility }\end{array}$ \\
\hline
\end{tabular}


supportive classroom environment. While the audience is high school instructors, college instructors interested in teaching in an inclusive way could also benefit from this resource. For additional in-class activities for teaching the nature of science that are culturally competent, instructors can refer to chapter 6 of the NAS resource Teaching about Evolution and the Nature of Science (NAS, 1998), which is freely downloadable on the National Academies Press website: www.nap.edu/catalogue/5787/ teaching-about-evolution-and-the-nature-of-science. The NAS has also published the resource Science, Evolution, and Creationism (NAS, 2008; also freely downloadable on the National Academies Press website: www.nap.edu/catalogue/11876/science -evolution-and-creationism), which gives an overview of the nature of science related to religion, the spectrum of creationist viewpoints on evolution, and several examples of how individuals have reconciled their religious faith with evolution. Science, Evolution, and Creationism can serve as an overview for instructors who are new to thinking about religious beliefs when teaching evolution and are apprehensive about their knowledge of ideas surrounding the relationship between religion and evolution. Finally, if instructors are interested in learning more about the potential experiences of their Christian students who are learning evolution and how those students might reconcile their religious beliefs and evolution, The Evolution Dialogues: Science, Christianity, and the Quest for Understanding (Baker and Miller, 2006) is a useful resource published by the American Association for the Advancement of Science and their program on the Dialogue of Science, Ethics, and Religion: www.aaas.org/page/ doser-books. This book is an overview of issues related to Christianity and evolution interspersed with a narrative about a Christian biology student who is struggling with learning about evolution. Even though these resources do not refer specifically to cultural competence, using one or all would be an excellent start to becoming a more culturally competent evolution instructor.

\section{EXTENDING CULTURAL COMPETENCE TO COMMUNICATION ABOUT EVOLUTION MORE BROADLY}

Our essay is primarily focused on the use of culturally competent instruction among college evolution instructors, but this framework has broader implications for communication to the public. Because most public communicators of science are similar to college biology instructors in their religious cultures and beliefs, we propose that they would also benefit from using culturally competent communication about evolution. In fact, some of the most well-known contemporary science communicators about evolution are infamous for their antireligious stances and often propagate negative stereotypes about religion and religious individuals while they are communicating with the public in videos, books, news articles, and public appearances (Dawkins, 2009; Coyne, 2015; Krauss, 2015). Although these scientists may see this strategy as aligning with a goal of decreasing the prevalence of religious beliefs within the United States, the evolution education literature suggests that these scientists, at best, are leaving acceptance of evolution rates stagnant, and at worst, may even be creating more negative attitudes toward evolution. For this reason, we encourage the use of cultural competence and ReCCEE practices for both college evolution instructors and public communicators of evolution.

\section{CONCLUSION}

We encourage instructors to consider the use of the Religious Cultural Competence in Evolution Education (ReCCEE) framework in the teaching of evolution at the college level. Instead of trying to change the religious beliefs of either instructors or students, we hope to bridge these gaps between secular and religious cultures when teaching evolution in hopes of increasing student acceptance of evolution, decreasing perceived conflict between evolution and religion, and increasing inclusivity in biology classes.

\section{ACKNOWLEDGMENTS}

We thank Paula Soneral, Christian Wright, and Katey Cooper for helpful feedback on earlier versions of this article and the rest of the Biology Education Research Lab at Arizona State University for their feedback on this work. Additionally, we acknowledge the National Science Foundation Graduate Research Fellowship for financial support of M.E.B.

\section{REFERENCES}

Anderson, D. L., Fisher, K. M., \& Norman, G. J. (2002). Development and evaluation of the Conceptual Inventory of Natural Selection. Journal of Research in Science Teaching, 39(10), 952-978. https://doi.org/10.1002/ tea. 10053

Astley, J., \& Francis, L. J. (2010). Promoting positive attitudes towards science and religion among sixth-form pupils: Dealing with scientism and creationism. British Journal of Religious Education, 32(3), 189-200.

Athanasiou, K., \& Papadopoulou, P. (2012). Conceptual ecology of the evolution acceptance among Greek education students: Knowledge, religious practices and social influences. International Journal of Science Education, 34(6), 903-924. https://doi.org/10.1080/09500693.2011.586072

Baker, C., \& Miller, J. B. (2006). The evolution dialogues: Science, Christianity, and the quest for understanding. Washington, DC: Program of Dialogue on Science, Ethics, and Religion, American Association for the Advancement of Science.

Barbour, I. G. (1990). Religion in an age of science. San Francisco: Harper \& Row

Barnes, M. E., \& Brownell, S. E. (2016). Practices and perspectives of college instructors on addressing religious beliefs when teaching evolution. CBE-Life Sciences Education, 15(2), ar18. https://doi.org/10.1187/cbe 15-11-0243

Barnes, M. E., Elser, J., \& Brownell, S. E. (2017a). The impact of a short evolution module on students' perceived conflict between evolution and religion. American Biology Teacher, 79(2), 104-111.

Barnes, M. E., Truong, J., \& Brownell, S. E. (2017b). Experiences of Judeo Christian students in biology classes. CBE-Life Sciences Education, 16(1), ar15.

Barnes, M. E., Truong, J. M., \& Brownell, S. E. (2018). Can six minutes of culturally competent evolution education reduce students' level of perceived conflict between evolution and religion? American Biology Teacher (in press).

Betancourt, J. R., Green, A. R., Carrillo, J. E., \& Ananeh-Firempong, O. (2003) Defining cultural competence: A practical framework for addressing racial/ethnic disparities in health and health care. Public Health Reports, 118(4), 293-302

Bishop, B. A., \& Anderson, C. W. (1990). Student conceptions of natural selection and its role in evolution. Journal of Research in Science Teaching, 27(5), 415-427. https://doi.org/10.1002/tea.3660270503

Brem, S. K., Ranney, M., \& Schindel, J. (2003). Perceived consequences of evolution: College students perceive negative personal and social impact in evolutionary theory. Science Education, 87(2), 181-206. https:// doi.org/10.1002/sce.10105

Brickhouse, N. W., Dagher, Z. R., Letts, W. J. IV., \& Shipman, H. L. (2000) Diversity of students' views about evidence, theory, and the interface between science and religion in an astronomy course. Journal of Research in Science Teaching, 37(4), 340-362. https://doi.org/10.1002/(SICI)1098 -2736(200004)37:4<340::AID-TEA4>3.0.CO;2-D 
Carter, B. E., \& Wiles, J. R. (2014). Scientific consensus and social controversy: Exploring relationships between students' conceptions of the nature of science, biological evolution, and global climate change. Evolution: Education and Outreach, 7(1), 6. https://doi.org/10.1186/s12052-014 -0006-3

Cavallo, A. M. L., White, K. J., \& McCall, David (2011). The mismatch among students' views about nature of science, acceptance of evolution, and evolutionary science understandings. Science Education Review, 10(2), $37-42$.

Clergy Letter Project. (2016). The Clergy Letter Project. Retrieved February 2, 2016, from https://theclergyletterproject.org

Cobern, B. (2004). Apples and oranges: A rejoinder to Smith and Siegel. Science \& Education, 13(6), 583-589. https://doi.org/10.1023/B:SCED $.0000042856 .33782 .7 \mathrm{~b}$

Cobern, W. W. (1994). Comments and criticism. Point: Belief, understanding, and the teaching of evolution. Journal of Research in Science Teaching, 31(5), 583-590. https://doi.org/10.1002/tea.3660310511

Cooper, K. M., \& Brownell, S. E. (2016). Coming out in class: Challenges and benefits of active learning in a biology classroom for LGBTQIA students. CBE-Life Sciences Education, 15(3), ar37.

Coyne, J. A. (2015). Faith versus fact: Why science and religion are incompatible New York: Penguin.

Dagher, Z. R., \& BouJaoude, S. (1997). Scientific views and religious beliefs of college students: The case of biological evolution. Journal of Research in Science Teaching, 34(5), 429-445. https://doi.org/10.1002/(SICI)1098 -2736(199705)34:5<429::AID-TEA2>3.0.CO;2-S

Dawkins, R. (2009). The God delusion, New York: Random House.

Deniz, H., Donnelly, L. A., \& Yilmaz, I. (2008). Exploring the factors related to acceptance of evolutionary theory among Turkish preservice biology teachers: Toward a more informative conceptual ecology for biological evolution. Journal of Research in Science Teaching, 45(4), 420-443. https://doi.org/10.1002/tea.20223

Donnelly, L. A., Kazempour, M., \& Amirshokoohi, A. (2008). High school students' perceptions of evolution instruction: Acceptance and evolution learning experiences. Research in Science Education, 39(5), 643-660. https://doi.org/10.1007/s11165-008-9097-6

Ecklund, E. H., \& Scheitle, C. P. (2007). Religion among academic scientists: Distinctions, disciplines, and demographics. Social Problems, 54(2), 289-307. https://doi.org/10.1525/sp.2007.54.2.289

Gallup. (2017). In US, Belief in Creationist View of Humans at New Low. Retrieved June 10, 2017, from www.gallup.com/poll/210956/belief -creationist-view-humans-new-low.aspx

Glaze, A. L., \& Goldston, M. J. (2015). U.S. science teaching and learning of evolution: A critical review of the literature 2000-2014. Science Education, 99(3), 500-518. https://doi.org/10.1002/sce.21158

Glaze, A. L., Goldston, M. J., \& Dantzler, J. (2014). Evolution in the southeastern USA: Factors influencing acceptance and rejection in pre-service science teachers. International Journal of Science and Mathematics Education, 13(6), 1189-1209. https://doi.org/10.1007/s10763-014-9541-1

Graffin, G. W., \& Provine, W. B. (2007). Macroscope: Evolution, religion and free will. American Scientist, 95(4), 294-297.

Großschedl, J., Konnemann, C., \& Basel, N. (2014). Pre-service biology teachers' acceptance of evolutionary theory and their preference for its teaching. Evolution: Education and Outreach, 7(1), 1-16. https://doi.org/ 10.1186/s12052-014-0018-z

Ham, K. (2010). The new answers book, Green Forest, AR: Master Books.

Harmsen, H., Bernsen, R., Meeuwesen, L., Thomas, S., Dorrenboom, G., Pinto, D., \& Bruijnzeels, M. (2005). The effect of educational intervention on intercultural communication: Results of a randomised controlled trial. British Journal of General Practice, 55(514), 343-350.

Hermann, R. S. (2012). Cognitive apartheid: On the manner in which high school students understand evolution without believing in evolution. Evolution: Education and Outreach, 5(4), 619-628. https://doi.org/ 10.1007/s12052-012-0446-6

Hill, J. P. (2014). Rejecting evolution: The role of religion, education, and social networks. Journal for the Scientific Study of Religion, 53(3), 575594. https://doi.org/10.1111/jssr.12127

Hill, P. C., \& Pargament, K. I. (2003). Advances in the conceptualization and measurement of religion and spirituality: Implications for physical and mental health research. American Psychologist, 58(1), 64-74. https://doi .org/https://doi.org.ezproxy1.lib.asu.edu/10.1037/0003-066X.58.1.64

Ingram, E. L., \& Nelson, C. E. (2006). Relationship between achievement and students' acceptance of evolution or creation in an upper-level evolution course. Journal of Research in Science Teaching, 43(1), 7-24. https://doi .org/10.1002/tea.20093

Jackson, D. F., Doster, E. C., Meadows, L., \& Wood, T. (1995). Hearts and minds in the science classroom: The education of a confirmed evolutionist. Journal of Research in Science Teaching, 32(6), 585-611. https:// doi.org/10.1002/tea.3660320606

Johnson, J. P., Lenartowicz, T., \& Apud, S. (2006). Cross-cultural competence in international business: Toward a definition and a model. Journal of International Business Studies, 37(4), 525-543. https://doi.org/ 10.1057/palgrave.jibs.8400205

Kaplan, S. (2016, November 10). Trump and Pence on science, in their own words. Washington Post. Retrieved June 10, 2017, from www.washingtonpost.com/ news/speaking-of-science/wp/2016/11/10/trump-and-pence-on-science -in-their-own-words/?utm_term=.c46d1d236dda

Kopplin, Z., Levin, J., Pesca, M., \& Steinberg, D. (2016, April 25). A day with Ken Ham. Slate. Retrieved February 14, 2017, from www.slate.com/articles/ news_and_politics/jurisprudence/2016/04/public_schools_are_visiting _ken_ham_s_creation_museum.html

Krauss, L. (2015, September 8). All scientists should be militant atheists. New Yorker, Retrieved May 19, 2017, from www.newyorker.com/news/news -desk/all-scientists-should-be-militant-atheists

Ladine, T. A. (2009). Attitudes of students at a private Christian liberal arts university toward the teaching of evolution. Evolution: Education and Outreach, 2(3), 386-392. https://doi.org/10.1007/s12052-009-0147-y

Manwaring, K. F., Jensen, J. L., Gill, R. A., \& Bybee, S. M. (2015). Influencing highly religious undergraduate perceptions of evolution: Mormons as a case study. Evolution: Education and Outreach, 8(1), 23. https://doi.org/ 10.1186/s12052-015-0051-6

Martin-Hansen, L. M. (2006). First-year college students' conflict with religion and science. Science \& Education, 17(4), 317-357. https://doi.org/ 10.1007/s11191-006-9039-5

Mead, L. S., Clarke, J. B., Forcino, F., \& Graves, J. (2015). Factors influencing minority student decisions to consider a career in evolutionary biology. Evolution: Education and Outreach, 8(1), 1-11. https://doi.org/10.1186/ s12052-015-0034-7

Merriam-Webster. (2017a). Definition of "culture." Retrieved March 29, 2017, from www.merriam-webster.com/dictionary/culture

Merriam-Webster. (2017b). Definition of "religion." Retrieved March 29, 2017, from www.merriam-webster.com/dictionary/religion

Merriam-Webster. (2017c). Definition of "religious." Retrieved June 10, 2017, from www.merriam-webster.com/dictionary/religious

Miller, K. R. (1999). Finding Darwin's god: A scientist's search for common ground between God and evolution. New York: Harper-Collins.

Nadelson, L. S., \& Hardy, K. K. (2015). Trust in science and scientists and the acceptance of evolution. Evolution: Education and Outreach, 8(1), 9.

Nadelson, L. S., \& Sinatra, G. M. (2009). Educational professionals' knowledge and acceptance of evolution. Evolutionary Psychology, 7(4).

Nadelson, L. S., \& Sinatra, G. M. (2010). Shifting acceptance of evolution: Promising evidence of the influence of the Understanding Evolution website. The Researcher, 23(1), 13-29.

Nadelson, L. S., \& Southerland, S. (2012). A more fine-grained measure of students' acceptance of evolution: Development of the Inventory of Student Evolution Acceptance-I-SEA. International Journal of Science Education, 34(11), 1637-1666.

National Academy of Sciences (NAS). (1998). Teaching about evolution and the nature of science. Washington, DC: National Academies Press.

NAS. (2008). Science, evolution, and creationism. Washington, DC: National Academies Press.

National Science Foundation, National Center for Science and Engineering Statistics. (2011). Doctorate recipients from U.S. universities: 2011 (Special Report NSF 13-301). Arlington, VA. Retrieved January 25, 2016, from www .nsf.gov/statistics/sed

Nehm, R. H., \& Schonfeld, I. S. (2007). Does increasing biology teacher knowledge of evolution and the nature of science lead to greater preference for the teaching of evolution in schools? Journal of Science 
Teacher Education, 18(5), 699-723. https://doi.org/10.1007/s10972 -007-9062-7

Pew Research Center. (2009). Scientists and belief Retrieved March 14, 2016, from www.pewforum.org/2009/11/05/scientists-and-belief

Pew Research Center. (2010). Religion among the millennials. Retrieved October 11, 2016, from www.pewforum.org/2010/02/17/religion-among -the-millennials

Rice, J. W., Olson, J. K., \& Colbert, J. T. (2010). University evolution education: The effect of evolution instruction on biology majors' content knowledge, attitude toward evolution, and theistic position. Evolution: Education and Outreach, 4(1), 137-144. https://doi.org/10.1007/s12052 -010-0289-y

Rissler, L. J., Duncan, S. I., \& Caruso, N. M. (2014). The relative importance of religion and education on university students' views of evolution in the Deep South and state science standards across the United States. Evolution: Education and Outreach, 7(1), 24. https://doi.org/10.1186/ s12052-014-0024-1

Robbins, J. R., \& Roy, P. (2007). The natural selection: Identifying \& correcting non-science student preconceptions through an inquiry-based, critical approach to evolution. American Biology Teacher, 69(8), 460-466. https://doi.org/10.1662/0002-7685(2007)69[460:TNSICN]2.0.CO;2

Rutledge, M. L., \& Sadler, K. C. (2007). Reliability of the Measure of Acceptance of the Theory of Evolution (MATE) instrument with university students. American Biology Teacher, 69(6), 332-335. https://doi.org/10.1662/ 0002-7685(2007)69[332:ROTMOA]2.0.CO;2

Rutledge, M. L., \& Warden, M. A. (2000). Evolutionary theory, the nature of science $\&$ high school biology teachers: Critical relationships. American Biology Teacher, 62(1), 23-31. https://doi.org/10.2307/4450822

Satlin, A. (2012). GOP rep.: Evolution, big bang "lies straight from the pit of hell." Huffington Post. Retrieved November 6, 2015, from www.huffingtonpost .com/2012/10/06/paul-broun-evolution-big-bang_n_1944808.html

Scharmann, L. C. (1990). Enhancing an understanding of the premises of evolutionary theory: The influence of a diversified instructional strategy School Science and Mathematics, 90(2), 91-100. https://doi.org/10 .1111/j.1949-8594.1990.tb12000.x

Scharmann, L. C. (1993). Teaching evolution: Designing successful instruction. AmericanBiology Teacher,55(8),481-486. https://doi.org/10.2307/4449720

Scharmann, L. C. (1994). Teaching evolution: The influence of peer teachers' instructional modelling. Journal of Science Teacher Education, 5(2), 66 76. https://doi.org/10.1007/BF02962859

Scharmann, L. C., \& Butler, W. (2015). The use of journaling to assess student learning and acceptance of evolutionary science. Journal of College Science Teaching, 45(1), 16.

Scharmann, L. C., Smith, M. U., James, M. C., \& Jensen, M. (2005). Explicit reflective nature of science instruction: Evolution, intelligent design, and umbrellaology. Journal of Science Teacher Education, 16(1), 27-41. https://doi.org/10.1007/s10972-005-6990-y

Schinske, J. N., Perkins, H., Snyder, A., \& Wyer, M. (2016). Scientist spotlight homework assignments shift students' stereotypes of scientists and enhance science identity in a diverse introductory science class. CBE-Life Sciences Education, 15(3), ar47.

Scott, E. (2014). Equipping scientists to better understand and converse with religious communities. Presented at the American Association for the Advancement of Science (Chicago, IL) Retrieved March 20, 2015, from https://ncse.com/node/15049

Sequist, T. D., Fitzmaurice, G. M., Marshall, R., Shaykevich, S., Marston, A., Safran, D. G., \& Ayanian, J. Z. (2010). Cultural competency training and performance reports to improve diabetes care for Black patients: A cluster randomized, controlled trial. Annals of Internal Medicine, 152(1), 40-46.

Settlage, J., \& Jensen, M. (1996). Investigating the inconsistencies in college student responses to natural selection test questions. Electronic Journal of Science Education, 1(1). Retrieved August 30, 2015, from https://ejse .southwestern.edu/article/view/7553
Short, S. D., \& Hawley, P. H. (2015). The effects of evolution education: Examining attitudes toward and knowledge of evolution in college courses. Evolutionary Psychology, 13(1), 67-88.

Sinatra, G. M., Southerland, S. A., McConaughy, F., \& Demastes, J. W. (2003) Intentions and beliefs in students' understanding and acceptance of biological evolution. Journal of Research in Science Teaching, 40(5), 510-528. https://doi.org/10.1002/tea.10087; https://doi.org/10.1007/BF00486589

Smith, M. U. (2009a). Current status of research in teaching and learning evolution: I. Philosophical/epistemological issues. Science \& Education, $19(6-8), 523-538$.

Smith, M. U. (2009b). Current status of research in teaching and learning evolution: II. Pedagogical issues. Science \& Education, 19(6-8), 539-571. https://doi.org/10.1007/s11191-009-9216-4

Smith, M. U., Siegel, H., \& Mclnerney, J. D. (1995). Foundational issues in evolution education. Science \& Education, 4(1), 23-46. https://doi.org/ 10.1007/BF00486589

Smith, M. U., Snyder, S. W., \& Devereaux, R. S. (2016). The GAENE-Generalized acceptance of evolution evaluation: Development of a new measure of evolution acceptance. Journal of Research in Science Teaching, 53(9), 1289-1315

Smithsonian Institution. (2015). Cultural and religious teaching strategies resource. Retrieved March 29, 2017, from https://humanorigins.si.edu/ education/teaching-evolution-through-human-examples

Southerland, S. A., \& Scharmann, L. C. (2013). Acknowledging the religious beliefs students bring into the science classroom: Using the bounded nature of science. Theory into Practice, 52(1), 59-65. https://doi.org/10 1080/07351690.2013.743778

Tanner, K., \& Allen, D. (2007). Cultural competence in the college biology classroom. CBE-Life Sciences Education, 6(4), 251-258. https://doi .org/10.1187/cbe.07-09-0086

Taylor, R. J., Chatters, L. M., \& Levin, J. (2003). Religion in the lives of African Americans: Social, psychological, and health perspectives. Sage.

Tervalon, M., \& Murray-García, J. (2010). Cultural humility versus cultural competence: A critical distinction in defining physician training outcomes in multicultural education. Journal of Health Care for the Poor and Underserved, 9(2), 117-125. https://doi.org/10.1353/hpu.2010 .0233

Tharoor, I. (2014, October 28). Pope Francis says evolution is real and God is no wizard. Washington Post. Retrieved November 6, 2015, from www.washingtonpost.com/news/worldviews/wp/2014/10/28/pope -francis-backs-theory-of-evolution-says-god-is-no-wizard

Verhey, S. D. (2005). The effect of engaging prior learning on student attitudes toward creationism and evolution. BioScience, 55(11), 996-1003. https://doi.org/10.1641/0006-3568(2005)055[0996:TEOEPL]2.0.CO;2

Wade, P., \& Bernstein, B. L. (1991). Culture sensitivity training and counselor's race: Effects on Black female clients' perceptions and attrition. Journal of Counseling Psychology, 38(1), 9.

Walter, E. M., Halverson, K. M., \& Boyce, C. J. (2013). Investigating the relationship between college students' acceptance of evolution and tree thinking understanding. Evolution: Education and Outreach, 6(1), 26. https://doi.org/10.1186/1936-6434-6-26

Wiles, J. R., \& Alters, B. (2011). Effects of an educational experience incorporating an inventory of factors potentially influencing student acceptance of biological evolution. International Journal of Science Education, 33(18), 2559-2585. https://doi.org/10.1080/09500693.2011.565522

Winslow, M. W., Staver, J. R., \& Scharmann, L. C. (2011). Evolution and personal religious belief: Christian university biology-related majors' search for reconciliation. Journal of Research in Science Teaching, 48(9), 10261049. https://doi.org/10.1002/tea.20417

Yasri, P., \& Mancy, R. (2016). Student positions on the relationship between evolution and creation: What kinds of changes occur and for what reasons? Journal of Research in Science Teaching, 53(3), 384-399. https:// doi.org/10.1002/tea.21302 